\title{
GESTÃO DE CARREIRAS
}

O tema da gestão de carreiras tem ganhado visibilidade e espaço no debate da literatura acadêmica. Surgido na década de 1960, o estudo das carrei ras na Administração assume papel importante nas duas últimas décadas e atual mente é considerado como ponto de convergência tanto de questões organi- zacionais - como necessidades expectativas e dilemas - na busca pela competitividade, quanto de questões individuais, na busca por identidade profissional e de como atuar em um cenário de intensa competição. Beatriz Maria Braga Lacombe, professora da FGV-EAESP, oferece as seguintes indicações:

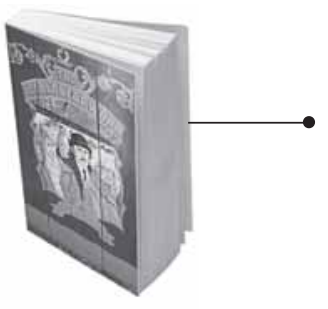

THE IDEOLOGY OF WORK. Peter Anthony. London: Tavistock, 1977. $340 \mathrm{p}$.

0 autor apresenta e discute 0 trabalho desde a Antiguidade até 0 movimento de reestruturação que atinge grande parte das organizações no mundo ocidental na década de 1980. 0 autor faz um alerta, ao descrever como os gestores acabaram se tornando vítimas de sua posição, de mediação entre o capital e o trabalho, e de suas próprias crenças e regras. Embora não seja uma obra especificamente sobre carreiras, sua leitura abre perspectivas e questionamentos importantes para o tema.

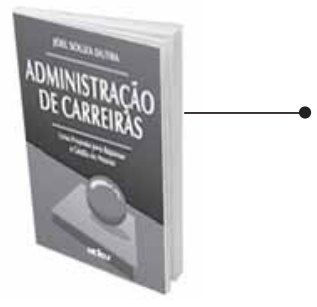

ADMINISTRAÇÃO DE CARREIRAS: uma proposta para repensar a gestão de pessoas. Joel Dutra. São Paulo: Atlas, 1996. $172 \mathrm{p}$.

A obra é pioneira sobre o tema do reposicionamento da carreira organizacional na literatura nacional, e apresenta a carreira como o eixo direcionador da relação entre pessoas e gestão. Partindo da literatura consolidada sobre o tema, como as fases, as escolhas e as âncoras de carreira e das transformações no contexto mundial, o autor destaca a necessidade e detalha os passos para o planejamento individual da carreira. 0 papel da empresa na construção das carreiras é discutido dentro do contexto da Gestão de Pessoas.

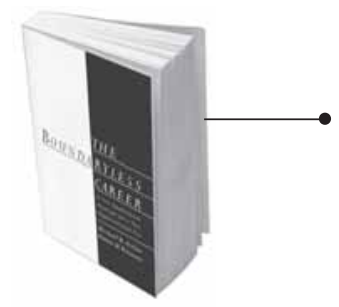

THE BOUNDARYLESS CAREER: A New Employment Principle for a New Organizational Era. Michael Arthur e Denise Rousseau. Oxford: Oxford University, 2001.349 p.

A coletânea organizada por Arthur e Rousseau reapresenta o conceito da carrei ra sem fronteiras, proposto na década de 1990, à luz de resultados de pesquisa e reflexões posteriores. Os capítulos são organizados de forma a apresentar o conceito e sua aplicabilidade, especial mente no contexto norte-americano, mostrando como são construídas as carreiras sem fronteiras, por quem e como, e suas implicações para a gestão das organizações e para a sociedade.

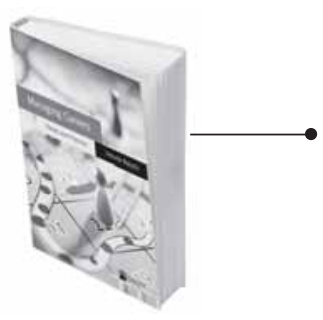

MANAGING CAREERS: Theory and Practice. Yehuda Baruch. Harlow, Essex, England: Financial Times Prentice Hall, 2004.299 p.

0 autor faz uma revisão da literatura sobre a gestão das carreiras no momento atual, discutindo os diversos novos conceitos e modelos que vêm sendo propostos sobre o tema. Conceitos como carreira sem frontei ras, carreira proteana e carrei ra inteligente são discutidos da perspectiva do desenvolvimento individual da carreira e da gestão das organizações. Temas como a gestão de carreiras internacionais e a diversidade também são abordados.

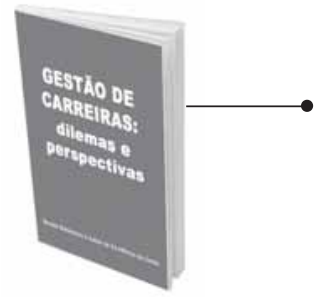

GESTÃO DE CARREIRAS: dilemas e perspectivas. Moisés Balassiano e Isabel de Sá Affonso da Costa. São Paulo: Altas, 2006. $190 \mathrm{p}$.

Esta obra atualiza e contextualiza o tema do desenvolvimento da carreira no cenário brasileiro. Os diversos autores revisitam e analisam os conceitos e modelos propostos nos últimos anos, e apresentando resultados de pesquisa e reflexões, apontam os dilemas e perspectivas identificados para as carreiras de profissionais liberais, para as carreiras organizacionais e públicas. No final, discute-se o desenvolvimento da carreira para as pessoas com mais de 40 anos, tema ainda pouco abordado na literatura nacional. 